\title{
CHANGES IN ANTIOXIDATIVE SYSTEMS AND MEMBRANE STABILITY INDEX OF CANOLA IN RESPONSE TO SALINE SOIL AND FERTILIZER TREATMENT APPLICATION ${ }^{\dagger}$
}

\author{
KHADEM-MOGHADAM N. ${ }^{1}$ \\ MOTESHAREZADEH B. ${ }^{1, *}$ \\ MAALI-AMIRI R. ${ }^{2}$
}

\author{
${ }^{1}$ Department of Soil Science and Engineering \\ Faculty of Agricultural Engineering \& Technology \\ University of Tehran, Karaj, Iran \\ ${ }^{2}$ Department of Agronomy and Plant Breeding \\ Faculty of Agronomy and Animal Science \\ University of Tehran, Karaj, Iran
}

Received: $15 / 03 / 2014$

Accepted: 23/05/2016

Available online: 02/06/2016 *to whom all correspondence should be addressed: e-mail: moteshare@ut.ac.ir

\section{ABSTRACT}

The ability of fertilizer treatments (O (Optimum level), OP (Optimum level + twice amount of $\mathrm{K}^{+}$), OZ (Optimum level + twice amount of $\mathrm{Zn}^{2+}$ ) and OZP (Optimum level + twice amount of $\mathrm{K}^{+}+$twice amount of $\left.\mathrm{Zn}^{2+}\right)$ ) to ameliorate salinity stress was studied in canola plants. In addition, fertilizer treatments; $\mathrm{O}, \mathrm{OZ}$ and OZP couldn't increase the activity of antioxidant enzymes, such as superoxide dismutase (SOD; EC 1.15.1.1), catalase (CAT; EC 1.11.1.6) and ascorbate peroxidase (APX; EC 1.11.1.11). When these plants were treated with OP treatment, the inhibitory effects of salinity stress were decreased by increasing the membrane stability index and antioxidant enzyme activities by ameliorating the salinity injury. These results suggested that $500\left(\mathrm{mg} \mathrm{kg}^{-1}\right)$ potassium has an important role in the enhancement of plant antioxidant systems and resistance to salinity in canola plants.

Keywords: zinc chelate, ameliorate, potassium, before flowering stage, canola

\section{Introduction}

High salinity is a major stress factor that affects crop production in arid and semi-arid regions (Ashraf and Q.Ali, 2008; Dolatabadian et al., 2008a; Hashemi et al., 2010). It is estimated that $20 \%$ of all cultivated lands in the world are salt-stressed (Sayar et al., 2010). It has been documented that salinity stress causes higher plasma membrane permeability and increases the oxidative stress in plants (Shafi et al., 2009). The deleterious effects of salinity stress on plant growth are (1) low osmotic potential of soil solution, (2) nutritional imbalance, (3) specific ion effects (Ahmad, 2012; Ashraf and Harris, 2004) On the other hand, plants have well-developed the protective system against oxidative stress (Alscher et al., 2002). One of the protective mechanisms is the enzymatic antioxidant system, which involves the sequential and simultaneous action of a number enzyme including superoxide dismutase (SOD; EC 1.15.1.1), catalase (CAT; EC 1.11.1.6) and ascorbate peroxidase (APX; EC 1.11.1.11) (Heidari, 2010). The present study was conducted to evaluation

\footnotetext{
${ }^{\dagger}$ Dedicated to the memory of the late Prof. Gh. R. Savaghebi (Professor of University of Tehran)
}

Khadem-Moghadam N., Motesharezadeh B. and Maali-Amiri R. (2016), Changes in antioxidative systems and membrane stability index of canola in response to saline soil and fertilizer treatment application, Global NEST Journal, 18(3), 508-515. 
the effect of fertilizer treatment on the salinity stress, antioxidant enzyme activities and membrane stability index of two canola cultivars. This approach may be useful to identify which fertilizer can apply in the salinity stress management.

\section{Materials and methods}

\subsection{Soil sample location, plant material, stress induction and fertilizer application}

The soil of this research, from the field of Tehran University, College of Agriculture and Natural Resources in the Karaj, Iran (1.2 (dS $\left.\mathrm{m}^{-1}\right)$ ) with the longitude and latitude $46^{\circ} 30^{\prime} 12^{\prime \prime}$ and $32^{\circ} 12^{\prime} 28^{\prime \prime}$ respectively was provided. Another soil with $14\left(\mathrm{dS} . \mathrm{m}^{-1}\right)$ salinity from the around of Karaj with the longitude and latitude $45^{\circ}$ $12^{\prime} 5.015^{\prime \prime}$ and $66^{\circ} 51^{\prime} 46^{\prime \prime}$ respectively were mixed to soil incorporated with $8\left(\mathrm{dS} \mathrm{m}^{-1}\right)$ is obtained. With this way, oxidative stress caused by soil salinity. Physical and chemical properties of this soil was determined (Table 1).

Table 1. Physical and chemical properties of soil tested

\begin{tabular}{|c|c|c|c|}
\hline Value & Characteristics & Value & characteristics \\
\hline 7.69 & $\mathrm{Mn}^{2+}\left(\mathrm{mg} \mathrm{kg}^{-1}\right)$ & Sandy clay loam & Soil texture \\
\hline 1.10 & $\mathrm{Cu}^{2+}\left(\mathrm{mg} \mathrm{kg}^{-1}\right)$ & 0.07 & $\mathrm{~N}$ total $(\%)$ \\
\hline 0.28 & $\mathrm{Zn}^{2+}\left(\mathrm{mg} \mathrm{kg}^{-1}\right)$ & 36.56 & SP (\%) \\
\hline 8.00 & $\mathrm{Fe}^{2+}\left(\mathrm{mg} \mathrm{kg}^{-1}\right)$ & 46.00 & ESP (\%) \\
\hline 14.24 & $\mathrm{~S}-\mathrm{SO}_{4}{ }^{2-}\left(\right.$ meq I$\left.^{-1}\right)$ & 0.34 & OM (\%) \\
\hline 8.00 & $\mathrm{EC}\left(\mathrm{dS} \mathrm{m^{-1 } )}\right.$ & 7.60 & $\mathrm{HCO}_{3}^{-}\left(\right.$meq I$\left.{ }^{-1}\right)$ \\
\hline 19.80 & CEC (meq/100g) & 0.00 & $\mathrm{CO}_{3}^{2-}\left(\mathrm{meq} \mathrm{I} \mathrm{l}^{-1}\right)$ \\
\hline 22.70 & $\mathrm{P}\left(\mathrm{mg} \mathrm{kg}^{-1}\right)$ & 3.51 & $\mathrm{Na}^{+}($meq l-1) \\
\hline 10.43 & $\mathrm{CaCO}_{3}(\%)$ & 0.55 & $\mathrm{Mg}^{2+}\left(\right.$ meq I $\left.{ }^{-1}\right)$ \\
\hline \multirow[t]{2}{*}{8.00} & $\mathrm{pH}$ & 0.94 & $\mathrm{Ca}^{2+}\left(\mathrm{meq}^{-1}\right)$ \\
\hline & & 184.86 & $\mathrm{~K}^{+}\left(\mathrm{mg} \mathrm{kg}^{-1}\right)$ \\
\hline
\end{tabular}

Fertilizer treatments during the growth stage, before starting the measurement of cultivation stage, as fertilizer $\mathrm{KNO}_{3}$ (for potassium), zinc chelate $7 \%$ (for zinc) and were applied as soil application. Similarly other nutrients were brought to optimum status. Since the critical levels of potassium and zinc are respectively 250 and $1.2\left(\mathrm{mg} \mathrm{kg}^{-1}\right)$, fertilizer treatments consisted of the twice potassium (500 mg kg$\left.{ }^{-1}\right)$, twice zinc $(2.4$ $\mathrm{mg} \mathrm{kg}^{-1}$ ), twice potassium plus zinc and control (pots that in the optimum nutrients, $250 \mathrm{mg} \mathrm{kg}^{-1}$ potassium and $1.2 \mathrm{mg} \mathrm{kg}^{-1}$ zinc) (Table 2).

Table 2. Combination of fertilizer treatments and cultivars

\begin{tabular}{llll}
\hline LO & Licord cultivar, optimum level of nutrients & Sarigol cultivar, optimum level of nutrients & SO \\
\hline \multirow{2}{*}{ LOP } & $\begin{array}{l}\text { Licord cultivar, optimum level of nutrients } \\
\text { twice amount of potassium }\end{array}$ & $\begin{array}{l}\text { Sarigol cultivar, optimum level of nutrients + } \\
\text { twice amount of potassium }\end{array}$ & SOP \\
\hline \multirow{2}{*}{ LOZ } & $\begin{array}{l}\text { Licord cultivar, optimum level of nutrients }+ \\
\text { twice amount of zinc }\end{array}$ & $\begin{array}{l}\text { Sarigol cultivar, optimum level of nutrients + } \\
\text { twice amount of zinc }\end{array}$ & SOZ \\
\hline \multirow{2}{*}{ LOZP } & $\begin{array}{l}\text { Licord cultivar, optimum level of nutrients }+ \\
\text { twice amount of (zinc plus potassium) }\end{array}$ & $\begin{array}{l}\text { Sarigol cultivar, optimum level of nutrients + } \\
\text { twice amount of (zinc plus potassium) }\end{array}$ & SOZP \\
\hline
\end{tabular}

To avoid increasing soil salinity, irrigation with distilled water during the plant growth took place. To prevent leaching of salts, the pots had no drainage. Canola seeds (Sarigol and Licord) were obtained from the Seed and Plant Improvement Institute of Karaj, Iran. Canola seeds were surface sterilized in a $5 \%$ sodium hypochlorite solution for $5 \mathrm{~min}$ and in $96 \%$ ethanol for $1 \mathrm{~min}$, and they were then thoroughly washed with 
distilled water. In the research greenhouse of College of Agricultural and Natural Resources in the $5 \mathrm{~kg}$ pots was sown. Plants were randomly harvested after five months, and the growth parameters, biochemical parameters and antioxidant status were analyzed. The experiment was carried out in a glasshouse with a photoperiod of $12 \mathrm{~h}$, irradiance of $250 \mu \mathrm{molm}^{-2} \mathrm{~s}^{-1}$ and air humidity between $60 \%$ and $65 \%$.

\subsection{Determination of antioxidants}

For extracting the antioxidant enzymes, fresh leaves $(0.5 \mathrm{~g})$ were ground in an ice cooled tissue grinder in 5 $\mathrm{ml}$ of $50 \mathrm{mM}$ cooled phosphate buffer ( $\mathrm{pH} \mathrm{7.8).} \mathrm{The} \mathrm{homogenate} \mathrm{was} \mathrm{centrifuged} \mathrm{at} \mathrm{15000 \times g} \mathrm{for} 20 \mathrm{~min}$ at $4{ }^{\circ} \mathrm{C}$. The supernatant was used for determining the activities of superoxide dismutase and catalase. The activity of SOD was determined following (Giannopolitis and Ries, 1977) by measuring its ability to inhibit the photoreduction of nitroblue tetrazolium (NBT). Catalase activity was determined following (Hatch, 1963) by monitoring the disappearance of $\mathrm{H}_{2} \mathrm{O}_{2}$ by measuring the decrease in absorbance at $240 \mathrm{~nm}$ of a reaction mixture containing $1.9 \mathrm{ml} \mathrm{H} \mathrm{H}_{2}, 1.0 \mathrm{ml}$ of $5.9 \mathrm{mM} \mathrm{H}_{2} \mathrm{O}_{2}$ in potassium phosphate buffer $(\mathrm{pH} 7.0)$, and $1.0 \mathrm{ml}$ extract. Ascorbate peroxidase activity was determined by following the decrease of ascorbate and measuring the change in absorbance at $290 \mathrm{~nm}$ for $1 \mathrm{~min}$ (Nakano and Asada, 1981).

\subsection{Determination of membrane stability index}

Membrane stability index (MSI) was determined as described by (Sairam et al., 2002). The leaves were excised and put in test tubes containing $10 \mathrm{ml}$ of deionized distilled water. These tubes were kept at $40^{\circ} \mathrm{C}$ for $30 \mathrm{~min}$

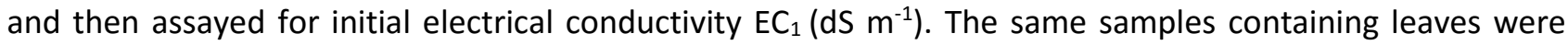
autoclaved at $100{ }^{\circ} \mathrm{C}$ for 15 min to determine $\mathrm{EC}_{2}\left(\mathrm{dS} \mathrm{m}^{-1}\right)$. Percent MSI was calculated as

$$
\operatorname{MSI}(\%)=\left[1-\left(\mathrm{EC}_{1} / \mathrm{EC}_{2}\right)\right] \times 100
$$

\subsection{Statistical analysis}

The experiment was carried out with a randomized complete block (RCB) design with three replicates. All data were subjected to analysis, and the significance of the differences among treatment means was tested at a $5 \%$ probability level. Due to data analysis and draw graphs, SPSS (version 17.0) and Excel softwares were used.

\section{Results and discussion}

As shown in Table 3, analysis of variance generally showed a significant effect of the fertilizer treatment and their interaction effect on antioxidant enzymes activity.

Table 3. Results of variance analysis (ANOVA) of Cultivar (C), Treatment (T), Time (S) and their interaction for antioxidant activity

\begin{tabular}{|c|c|c|c|c|}
\hline \multirow[t]{2}{*}{ SOV } & \multirow{2}{*}{ df } & \multicolumn{3}{|c|}{ Mean squares } \\
\hline & & SOD $\left(U \mathrm{mg}^{-1} \mathrm{fw}\right)$ & CAT $\left(n m o l ~ g^{-1}\right.$ fw) & APX $\left(\mu \mathrm{mol} \mathrm{mg}^{-1} \mathrm{fw}\right)$ \\
\hline Cultivar (C) & 1 & $0.013^{*}$ & $0.008^{\mathrm{ns}}$ & $0.115^{\mathrm{ns}}$ \\
\hline Treatment $(\mathrm{T})$ & 3 & $0.011^{* *}$ & $0.027^{* *}$ & $0.426^{* *}$ \\
\hline Time $(\mathrm{H})$ & 2 & $0.018^{* *}$ & $0.0035^{\mathrm{ns}}$ & $0.315^{*}$ \\
\hline $\mathrm{C} \times \mathrm{T}$ & 7 & $0.010^{* *}$ & $0.006^{* *}$ & $0.426^{* *}$ \\
\hline $\mathrm{C} \times \mathrm{H}$ & 5 & $0.011^{* *}$ & $0.007^{\mathrm{ns}}$ & $0.195^{*}$ \\
\hline $\mathrm{T} \times \mathrm{H}$ & 11 & $0.008^{* *}$ & $0.004^{* *}$ & $0.285^{* *}$ \\
\hline $\mathrm{C} \times \mathrm{T} \times \mathrm{H}$ & 23 & $0.007^{* *}$ & $0.003^{* *}$ & $0.252^{* *}$ \\
\hline Error & - & 0.001 & 0.012 & 0.010 \\
\hline CV (\%) & - & 1.21 & 1.32 & 2.1 \\
\hline
\end{tabular}

Numbers represent F-values at $5 \%$ level.

${ }^{*}$ and ${ }^{* *}$, significant at $\mathrm{P}<0.05$ and $\mathrm{P}<0.01$, respectively; ${ }^{\text {ns }}$, non-significant. 
The activity of antioxidant enzymes such as SOD significantly increased in the before flowering stage as compared to flowering stage and after flowering stage but this increasing were seen in the OP treatment (Figure 1 and 2).
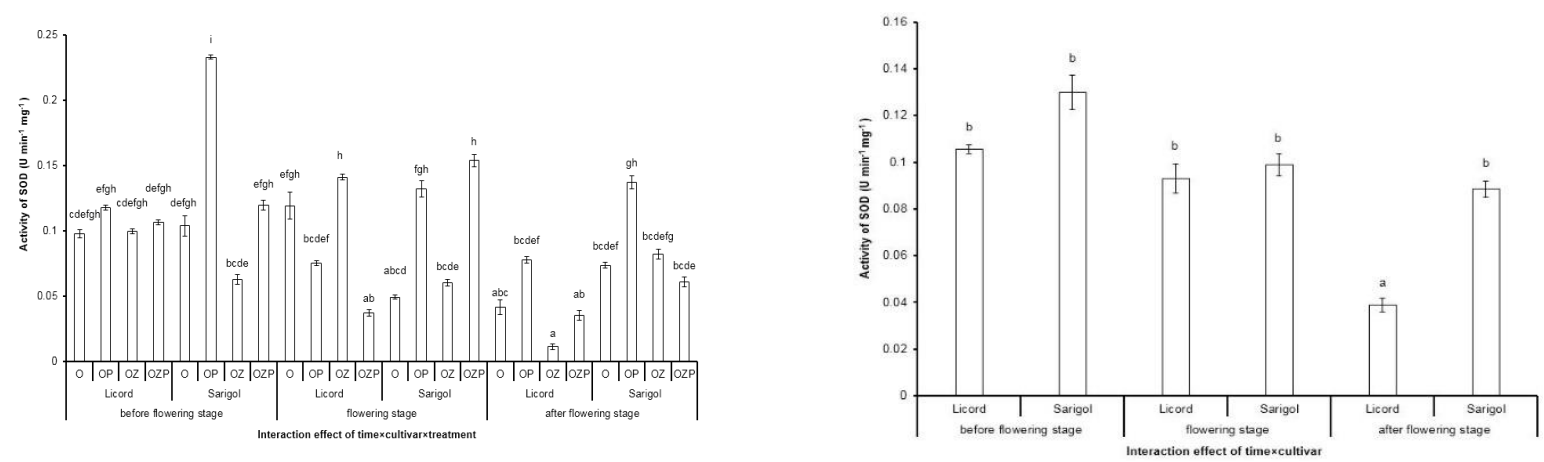

Figure 1. Interaction effect of three sampling times and two cultivars of canola on the activity of SOD (right) and interaction effect of three sampling times, cultivars and fertilizer treatments (left). Different letters indicate significant differences at $\mathrm{P}<0.05$
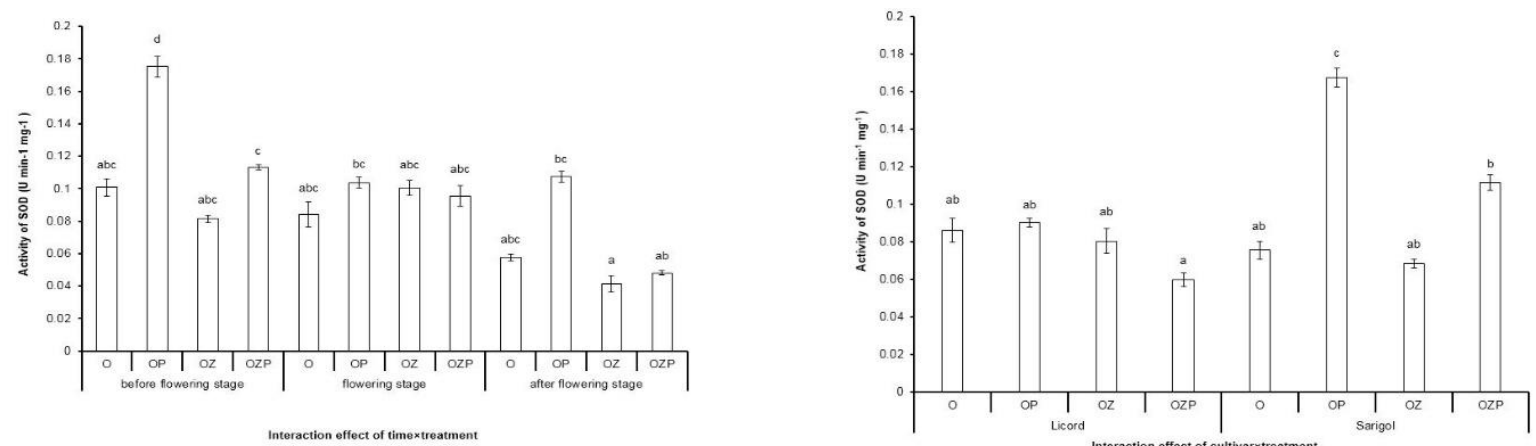

Figure 2. Interaction effect of cultivars and fertilizer treatments (right) and interaction effect of three sampling times and fertilizer treatments on the activity of SOD (left). Different letters indicate significant differences at $\mathrm{P}<0.05$

Fertilizer treatment especially OP treatment significantly increased interaction effect of CAT activity in the before flowering stage when compared to the activity in the flowering stage and after flowering stage except the interaction effect of $\mathrm{C} \times \mathrm{H}$ (Figure 3 and 4). OP treatment significantly increased interaction effect of APX activity in the before flowering stage when compared to the activity in the flowering stage and after flowering stage (Figure 5 and 6). Table 4, shows that fertilizer treatment and cultivar have a significant effect on the MSI but the interaction effect of $\mathrm{C} \times \mathrm{T}$ has not significant. OP treatment and Sarigol cultivar have a significant effect on the MSI (Figure 7).

According to the Table 3, the effect of fertilizer treatments on the antioxidants activity (SOD, CAT and GPX) and also interaction effects of cultivarxtime and timexcultivar and cultivarxtimextreatment at $\mathrm{P}<0.01$ were significant. The effect of time and cultivarxtime on activity of catalase was not significant.

Table 4 shows the effect of cultivar and treatment on the membrane stability was significant but their interaction effect was not significant. 


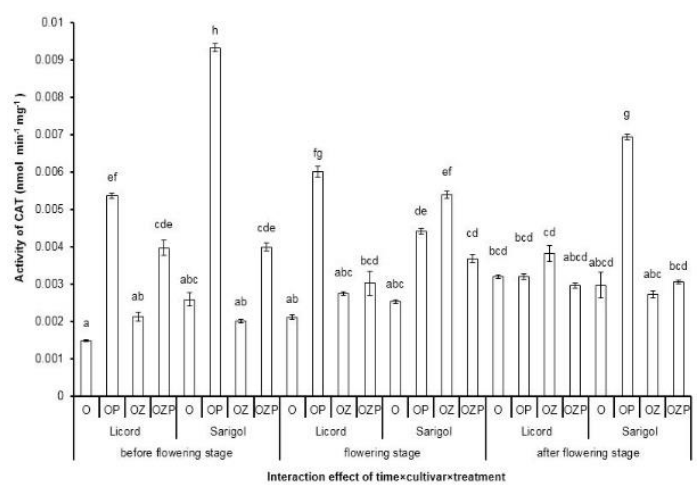

Figure 3. Interaction effect of three sampling times, two cultivars of canola and fertilizer treatments on the activity of CAT. Different letters indicate significant differences at $\mathrm{P}<0.05$

Reactive oxygen species (ROS) are produced in both unstressed and stressed cells and SODs constitute the first line of defense against ROS (Alscher et al., 2002). In fact, SODs converted ROS to the hydrogen peroxide $\left(\mathrm{H}_{2} \mathrm{O}_{2}\right)$ and oxygen. However, hydrogen peroxide is also toxic to cells and has to be further detoxified by CAT and peroxidases such as APX to water and oxygen (Tavallali et al., 2010). APX enzymes are distributed in almost every compartment of plant cells and participate in the removal of $\mathrm{H}_{2} \mathrm{O}_{2}$ as part of the ascorbateglutathione (Bonifacio et al., 2011). Hydrogen peroxide is also scavenged by CAT (Dolatabadian et al., 2008b) this enzyme converts $\mathrm{H}_{2} \mathrm{O}_{2}$ to the $\mathrm{H}_{2} \mathrm{O}$.
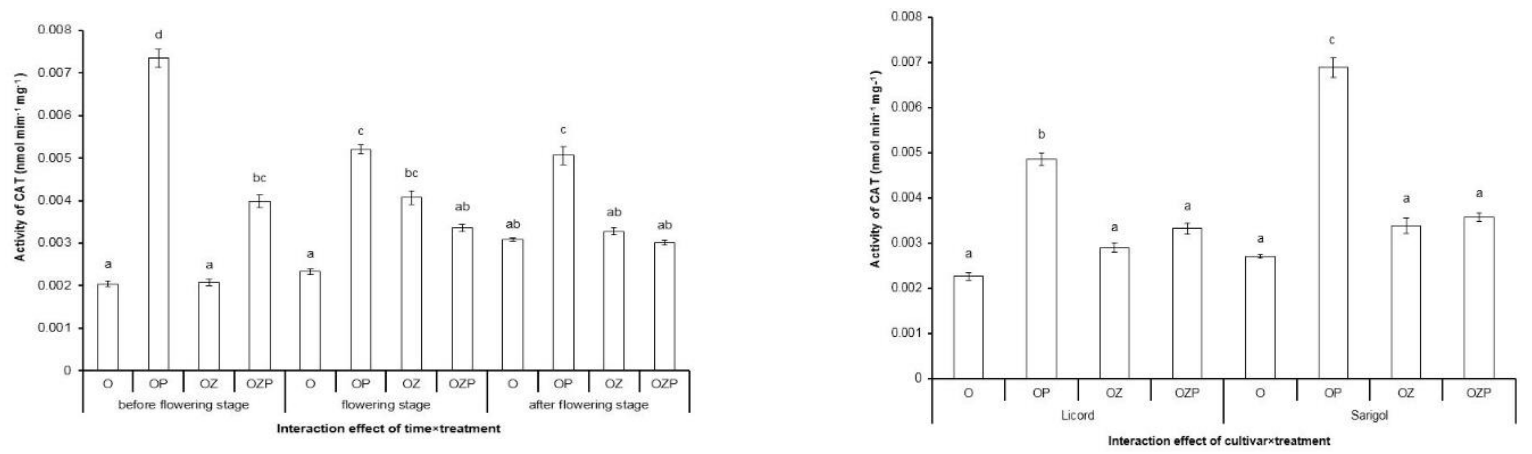

Figure 4. Interaction effect of cultivars and fertilizer treatments (right) and interaction effect of three sampling times and cultivars of canola on the activity of CAT (left). Different letters indicate significant differences at $\mathrm{P}<0.05$

Table 4. Results of variance analysis (ANOVA) of Cultivar (C), Treatment (T) and their interaction for membrane stability index (MSI)

\begin{tabular}{|c|c|c|}
\hline \multirow{2}{*}{ SOV } & \multirow{2}{*}{ df } & Mean square \\
\hline & & MSI (\%) \\
\hline Cultivar (C) & 1 & $220.39^{*}$ \\
\hline Treatment $(\mathrm{T})$ & 3 & $198.67^{* *}$ \\
\hline $\mathrm{C} \times \mathrm{T}$ & 7 & $66.88^{\mathrm{ns}}$ \\
\hline Error & - & 36.59 \\
\hline CV (\%) & - & 2.1 \\
\hline
\end{tabular}

Numbers represent F-values at $5 \%$ level.

${ }^{*}$ and ${ }^{* *}$, significant at $\mathrm{P}<0.05$ and $\mathrm{P}<0.01$, respectively; ${ }^{\text {ns }}$, non-significant. 

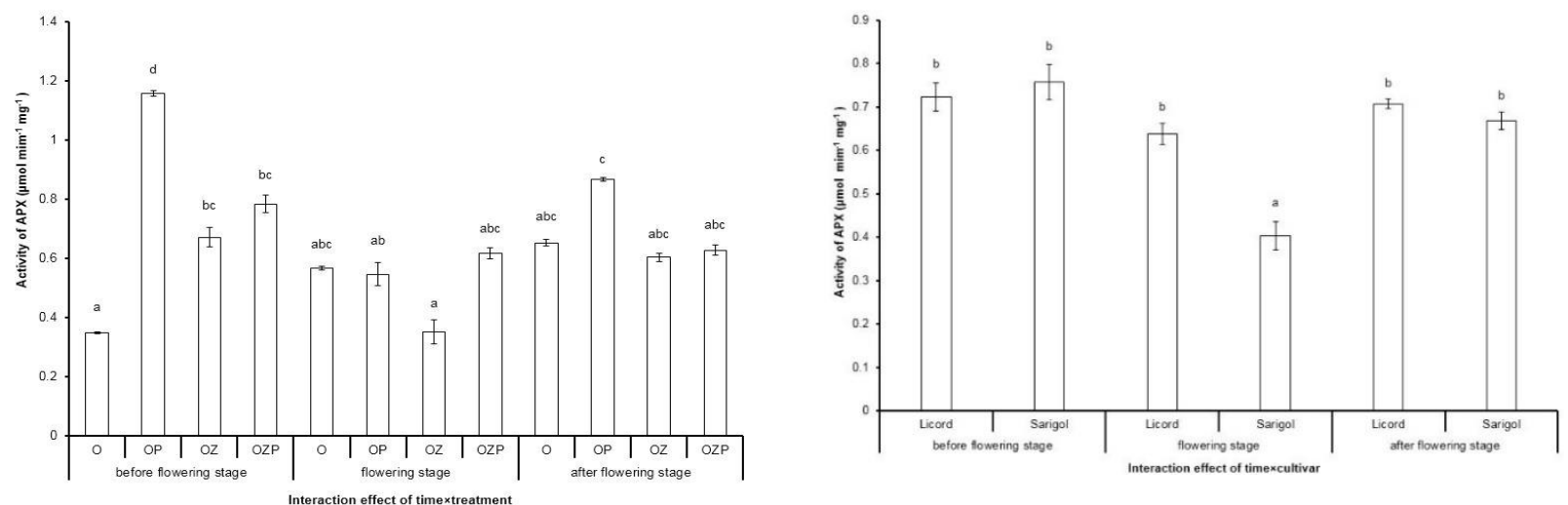

Figure 5. Interaction effect of three sampling times and two cultivars of canola (right) and interaction effect of three sampling times and fertilizer treatments on the activity of APX (left). Different letters indicate significant differences at $\mathrm{P}<0.05$

Maintain a high cytosolic $\mathrm{K}^{+} / \mathrm{Na}^{+}$ratio is one of the crucial mechanisms to salt tolerance (Sergey and Tracey, 2007). Soil salinity is known to adversely affect potassium uptake and it can often be ameliorated by increased potassium supply (Szczerbab et al., 2009; Wang et al., 2013). Potassium plays important roles in metabolisms like enzyme activities and protein synthesis (Y. Wen et al., 2011). To enhance agricultural production in saline soils, it is necessary to ensure high crop production against environmental stresses. The present work demonstrated that OP treatment enhanced salinity tolerance in canola cultivars, which led to higher antioxidant potentials under salinity stress conditions when compared to $\mathrm{O}, \mathrm{OZ}$ and OZP treatment. OP treatments caused activity SOD, CAT and APX enzymes when compared to the O, OZ and OZP, at least $18.7 \%$, $25.65 \%$ and $9.63 \%$ higher than others, respectively. In the study that were carried out on the rapeseed seedling for investigation response of antioxidant enzymes activity with excess zinc, this research showed that NADH oxidase and peroxidase activity increased in leaves and roots of plants under high zinc, but SOD, CAT and APX activities decreased (Wang et al., 2009).
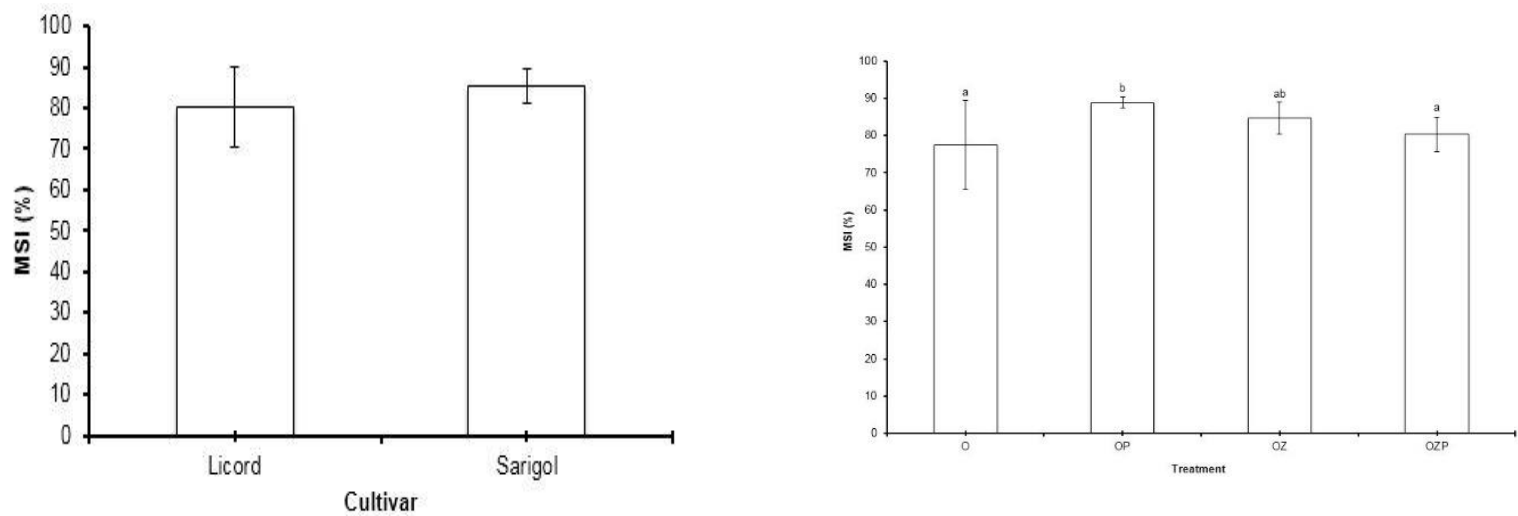

Figure 6. Interaction effect of cultivars and fertilizer treatments (right) and interaction effect of fertilizer treatments, two cultivars and three sampling times on the activity of APX (left). Different letters indicate significant differences at $\mathrm{P}<0.05$

According to the results of Heidari and Jamshidi, (2011), potassium treatment increased activity of CAT and GPX in the pearl millet. Shahbazi et al., (2011) resulted leaf antioxidant activities of SOD, APX and glutathione 
reductase (GR) were increased by salinity increase up to $150 \mathrm{mM} \mathrm{NaCl}$ concentration. Heidari (2010) resulted by increasing $\mathrm{NaCl}$ levels to $300 \mathrm{mmol} \mathrm{I}^{-1}$, the activities of CAT and APX in the canola cultivars increased but guaiacol peroxidase (GPX) in all cultivars decreased. Interaction effects of fertilizer treatments and canola cultivars showed OP treatment and Sarigol cultivar have a higher MSI percentage $(0.89 \%)$ rather than others. Research indicated that application of $\mathrm{K}$ fertilizer generally increased crop yield as well as nutritional quality (Wang et al., 2008). Tavallali et al., (2010) reported that Zn supplement efficiently reduced oxidative stress, electrolyte leakage and increased activity of antioxidant enzymes (SOD, CAT and APX) in the salinity stress conditions in (Pistacia vera L.) seedlings. Therefore, the results of this study suggested that OP treatment enhanced antioxidant enzymes (SOD, CAT and APX) in the before flowering stage and increased MSI percentage in Brassica napus plants, thus, improving plant tolerance to salinity. Potassium is an essential nutrient that affects most of the biochemical and physiological processes that influence plants metabolisms and it also contributes to the survival of plants exposed to various biotic and abiotic stresses.
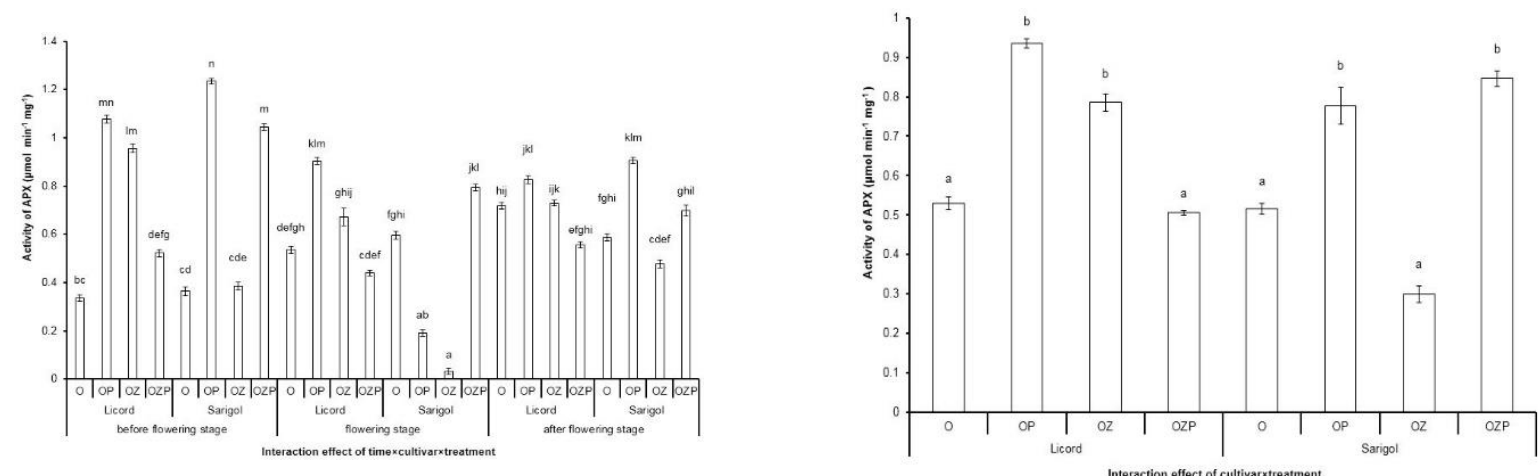

Figure 7. Effect of fertilizer treatments (right) and the effect of cultivars on MSI (\%) (left). Different letters indicate significant differences at $\mathrm{P}<0.05$

\section{REFERENCES}

Ahmad B. (2012), Effect of ascorbic acid and silicium on photosynthesis, antioxidant enzyme activity, and fatty acid contents in canola exposure to salt stress, Journal of Integrative Agriculture 11(10), 1610-1620.

Alscher R.G., Erturk N. and Heath L.S. (2002), Role of superoxide dismutases (SODs) in controlling oxidative stress in plants, Journal of Experimental Botany, 53, 1331-1341.

Ashraf M. and Harris P.J.C. (2004), Potential biochemical indicators of salinity tolerance in plants, Plant Science 166, 3-16.

Ashraf M. and Ali Q. (2008), Relative membrane permeability and activities of some antioxidant enzymes as the key determinants of salt tolerance in canola (Brassica napus L.), Environmental and Experimental Botany, 63, 266-273.

Bonifacio A., Martins M.O., Ribeiro C.W., Fontenele A.V., Carvalho F.E.L., Margis-Pinheiro M. and Silveira J.A.G. (2011), Role of peroxidases in the compensation of cytosolic ascorbate peroxidase knockdown in rice plants under abiotic stress, Plant, Cell and Environment, 34, 1705-1722.

Dolatabadian A., Sanavy S.A.M.M. and Chashmi N.A. (2008a), The effects of foliar application of ascorbic acid (vitamin C) on antioxidant enzymes activities, lipid peroxidation and proline accumulation of canola (Brassica napus L.) under conditions of salt stress, J. Agronomy and Crop Science 194, 206-213.

Dolatabadian A., Sanavy S.A.M.M. and Chashmi N.A. (2008b), The Effects of Foliar Application of Ascorbic Acid (Vitamin C) on Antioxidant Enzymes Activities, Lipid Peroxidation and Proline Accumulation of Canola (Brassica napus L.) under Conditions of Salt Stress, Journal of Agronomy and Crop Science, 194, 206-213.

Giannopolitis C.N. and Ries S.K. (1977), Superoxide dismutase. I. Occurrence in higher plants, Plant Physiology, 59, 309-314. 
Hashemi A., Abdolzadeh A. and Sadeghipour H.R. (2010), Beneficial effects of silicon nutrition in alleviating salinity stress in hydroponically grown canola, Brassica napus L., plants, Soil Science \& Plant Nutrition, 56, $244-253$.

Hatch M.D. and Glasziou K.T. (1963), Sugar accumulation cycle in sugar cane. ii. relationship of invertase activity to sugar content \& growth rate in storage tissue of plants grown in controlled environments, Plant Physiology 38(3), 344-348.

Heidari M. (2010), Nucleic acid Metabolism, proline concentration and antioxidants enzyme activity in canola (Brassica nupus L.) under salinity stress, Agricultural Sciences in China, 9(4), 504-511.

Heidari M. and Jamshidi P. (2011), Effects of salinity and potassium application on antioxidant enzyme activities and physiological parameters in Pearl Millet, Agricultural Sciences in China, 10(2), 228-237.

Nakano Y. and Asada K. (1981), Hydrogen peroxide is scavenged by ascorbate specific peroxidase in spinach chloroplasts, Plant Cell Physiology, 22, 867-880.

Sairam R.K., Rao K.V. and Srivastava G.C. (2002), Differential response of wheat genotypes to long term salinity stress in relation to oxidative stress, antioxidant activity and osmolyte, Plant Science, 163, 1037-1046.

Sayar R.H., Bchini M.M. and Ezzine M. (2010), Effects of salt and drought stresses on germination, emergence and seedling growth of Durum wheat (Triticum durum Desf.), Journal of Agricultural Research 5(15), 2008-2016.

Sergey S. and Tracey A.C. (2007), Potassium transport and plant salt tolerance, Physiologia Plantarum, 133, $651-669$.

Shafi M., Bakht J., Hassan M.J., Raziuddin M. and Zhang G. (2009), Effect of Cadmium and Salinity Stresses on Growth and Antioxidant Enzyme Activities of Wheat (Triticum aestivum L.), Bull Environ Contam Toxicol, 82, 772-776.

Shahbazi E., Arzani A. and Saeidi G. (2011), Effects of nacl treatments on seed germination and antioxidant activity of canola (Brassica napus L.) cultivars, Bangladesh Journal of Botany 41(1), 67-73.

Szczerbab M.W., Brittoa D.T. and Kronzucker H.J. (2009), $\mathrm{K}^{+}$transport in plants: Physiology and molecular biology, Journal of Plant Physiology, 166, 447-466.

Tavallali V., Rahemi M., Eshghi S., Kholdebarin B. and Ramezanian A. (2010), Zinc alleviates salt stress and increases antioxidant enzyme activity in the leaves of pistachio (Pistacia vera L. 'Badami') seedlings, Turkish Journal of Agriculture and Forestry, 34, 349-359.

Wang C., Zhang S.H., Wang P.F., Hou J., Zhang W.J., Li W. and Lin Z.P. (2009), The effect of excess Zn on mineral nutrition and antioxidative response in rapeseed seedlings, Chemosphere, 75, 1468-1476.

Wang M., Zheng Q., Shen Q. and Guo S. (2013), The critical role of potassium in plant stress response, International Journal of Molecular Science, 14, 7370-7390.

Wang Z.-H., Li S.-X., and Malhi S. (2008), Effects of fertilization and other agronomic measures on nutritional quality of crops, Journal of the Science of Food and Agriculture, 88, 7-23.

Y. Wen X., Yu T.Z., Amjad M.H., Jian W.Z., Lin Liang G., Qian L. and Wei W. (2011), Optimization of potassium for proper growth and physiological response of Houttuynia cordata Thunb, Environmental and Experimental Botany, 71, 292-297. 